\title{
Kajian Terhadap Hak atas Kebebasan Beragama dan Berkeyakinan serta Hak atas Pekerjaan
}

\author{
Duwi Handoko \\ Sekolah Tinggi Ilmu Hukum Persada Bunda, Pekanbaru \\ Email:sepihak@gmail.com
}

Info Artikel:

| Diterima: 09 Januari 2019

| Disetujui: 01 Juli 2019

| Dipublikasikan: 02 Juli 2019

\begin{abstract}
The purpose of this study is to analyze the freedom to embrace religion and belief and fulfill the right to work in Indonesia. This type of research is normative legal research specifically discussing human rights in the field of religion and work. Regulation on the role and sanction for the government in the context of guaranteeing religious freedom, especially for Muslims, is very important. One form of legal vacuum in the regulation of religious freedom in Indonesia is in the context of the release of someone from Islam who aims to save humanity (of course also for other religions in Indonesia) and embrace other religions of his own free will. Regulations regarding the role and sanctions for the government in the context of guaranteed rights to obtain decent jobs, especially at productive age, are very important. Technically, it is clearly impossible for employers to recruit workers if there are no jobs in accordance with the capacity of the company's needs. From this, it can be said that the fulfillment of the right to work has a correlation with other types of rights so that a worker can have competence. The amount of unemployment that cannot be reduced by the Indonesian government and discriminatory treatment is a form of violation of the right to work.

Keywords: Freedom to Embrace Religion and Belief, Fulfill the Right to Work in Indonesia, Religion and Work
\end{abstract}

\begin{abstract}
Abstrak
Tujuan dari penelitian ini adalah melakukan analisis terhadap kebebasan untuk memeluk agama dan berkeyakinan serta pemenuhan hak atas pekerjaan di Indonesia. Jenis penelitian ini adalah penelitian hukum normatif tentang hak asasi manusia di bidang agama dan pekerjaan. Regulasi tentang peran dan pemberian sanksi bagi pemerintah dalam konteks terjaminnya kebebasan beragama, terlebih pada pemeluk agama Islam, adalah hal yang sangat penting. Salah satu bentuk kekosongan hukum dalam regulasi kebebasan beragama di Indonesia adalah dalam konteks keluarnya seseorang dari agama Islam yang bertujuan untuk menyelamatkan manusia (tentu juga bagi pemeluk agama lainnya di Indonesia) dan memeluk agama lain atas kehendaknya sendiri dan tanpa paksaan siapapun. Regulasi tentang peran dan pemberian sanksi bagi pemerintah dalam konteks terjaminnya hak untuk memperoleh pekerjaan yang layak, terlebih pada usia produktif, adalah hal yang sangat penting. Secara teknis, jelas tidak mungkin pengusaha akan merekrut pekerja/buruh jika tidak tersedia pekerjaan sesuai dengan kapasitas kebutuhan perusahaannya. Dari hal ini maka dapat dikatakan bahwa pemenuhan terhadap hak atas pekerjaan memiliki korelasi dengan jenis hak-hak lainnya sehingga seorang pekerja dapat memiliki kompetensi. Jumlah pengangguran yang tidak bisa dikurangi oleh pemerintah Indonesia dan perlakuan yang diskriminatif adalah bentuk pelanggaran hak atas pekerjaan.
\end{abstract}

Kata kunci: Agama dan Pekerjaan, Kebebasan untuk Memeluk Agama dan Berkeyakinan, Pemenuhan Hak atas Pekerjaan di Indonesia 


\section{A. PENDAhULUAN}

Guna mencapai cita-cita Negara Hukum atau rechtsstaat, secara filosofis dapat ditelusuri keberadaannya melalui pemikiran Fichte yang menyebutkan, hak asasi individu harus dilindungi oleh negara. Fichte mendalilkan kehadiran sebuah institusi yang bebas dari kekuasaan negara dan diperlukan untuk menguji keabsahan tindakan negara. ${ }^{1}$ Pembahasan Hak Asasi Manusia (HAM) dalam konteks internasional, diklasifikasikan ke dalam 3 (tiga) generasi. Generasi pertama adalah tentang HAM Sipil dan Politik (SIPOL). HAM generasi pertama ini lebih mengedepankan kebebasan masyarakat dari pengekangan negara. Ia lebih menghargai ketiadaan intervensi negara dalam pencarian martabat manusia yang dipengaruhi oleh pemikiran kaum reformis dan oleh filsafat politik individualisme liberal serta doktrin sosial ekonomi liassez-faire. $^{2}$

Kedua, HAM EKOSOB, yang muncul lebih karena ketimpangan ekonomi dunia yang dikuasai kaum kapitalis yang telah banyak memunculkan pelanggaran dan penyelewengan di berbagai belahan dunia. Selanjutnya, generasi ketiga tentang hak untuk membangun solidaritas (solidarity rights) yang muncul sebagai bentuk bangkitnya nasionalisme Dunia Ketiga menghadapi tekanan dari negara-negara maju. ${ }^{3} \mathrm{HAM}$ tidak bisa diintervensi oleh manusia di luar dirinya atau oleh kelompok atau oleh lembaga-lembaga manapun untuk meniadakannya. Hak Asasi Manusia, pada hakekatnya telah ada sejak seorang

\footnotetext{
${ }^{1}$ Ahmad Syahrizal, Peradilan Konsitusi, (Jakarta: Pradnya Paramita, 2006), hlm. 59.

${ }^{2}$ Eko Riyadi dan Supriyanto Abdi (Editor), Mengurai Kompleksitas Hak Asasi Manusia (Kajian Multi Perspektif), (Yogyakarta: Pusat Studi Hak Asasi Manusia Universitas Islam Indonesia (PUSHAM UII), 2007), hlm. 247.

${ }^{3}$ Ibid., hlm. 247-248.
}

manusia masih berada dalam kandungan ibunya hingga ia lahir dan sepanjang hidupnya hingga pada suatu saat ia meninggal dunia. ${ }^{4}$

Kemanusiaan manusia diakui sebagai konsensus universal yang justru tetap melekat sebagai pemilik asasi mutlak atas dasar kemanusiaan, terlepas dari perbedaan jenis kelamin, warna kulit, status ekonomi, kewarganegaraan, agama, dan lain-lain. Inilah selanjutnya yang menghasilkan lahirnya konsep HAM. Manusia adalah pengemban fitrah kemanusiaan yang bersifat universal. ${ }^{5}$ Isu HAM mengedepan pasca Perang Dingin. isu tersebut begitu kuat dihembuskan oleh umumnya negaranegara demokrasi Barat terutama dalam merespon perkembangan politik internal di beberapa negara sosialis/ komunis dan pada negara-negara Dunia Ketiga, isu HAM tersebut setidaknya telah menjadi bagian dari pengambilan kebijakan internasional dari negara semacam Amerika Serikat, Inggris ataupun Perancis. ${ }^{6}$

Orang-orang yang terlibat dalam memperjuangkan HAM, khususnya hak dasar manusia, menjadi tema sentral yang sangat menarik perhatian pada abad ini. Walau baru dirumuskan secara eksplisit pada abad ke-18, aspek hak asasi manusia telah dikenal sejak zaman Yunani dengan pemunculan teori hukum kodrat sekitar 600-400 SM. Masalah HAM juga telah dibahas oleh beragam agama ratusan tahun lampau, seperti Kristen (dalam Kitab Perjanjian Lama) dan Islam (termaktub di dalam Al-

\footnotetext{
${ }^{4}$ A. Bazar Harahap dan Nawangsih Sutardi, Hak Asasi Manusia dan Hukumnya, (Jakarta: Pecirindo, 2006), hlm. 6 .

${ }^{5}$ Majda El Muhtaj, Dimensi-dimensi HAM: Mengurai Hak Ekonomi, Sosial, dan Budaya, (Jakarta: RajaGrafindo Persada, 2008), hlm. 37.

${ }^{6}$ Andi Yusran, Dinamika Politik Indonesia: Dari Transisi ke Transisi, (Pekanbaru: The Institute for Regional Development and Policy Studies (ReD PoSt Institute), 2006), hlm. 4.
} 
Quran). ${ }^{7}$ Tonggak sejarah keberpihakan Islam terhadap HAM adalah dideklarasikannya Piagam Madinah. ${ }^{8}$ Meskipun harus diakui bahwa HAM suatu negara berbeda dengan negara lain dalam praktek penegakan hukum maupun dalam bentuk perlindungan serta pelaksanaan hukumnya. ${ }^{9}$

Di Indonesia, terdapat sepuluh kategori sebagai pedoman, yang bukan saja bagi Komnas HAM dalam memilahmilah kasus HAM tetapi juga bagi masyarakat umum yang mengadukan persoalan pelanggaran HAM kepada Komnas HAM, baik secara individual maupun kelompok. Untuk pengaduan kelompok, Komnas HAM tidak melakukan pembatasan. Pengaduan tersebut dilakukan secara tertulis, yaitu dengan mencantumkan tanda tangan dan nama jelas pengadu, alamat secara jelas dan tanggal pengaduan. Pengadu juga dapat melakukan konsultasi terlebih dahulu sebelum mendaftarkan pengaduannya. Jika pengaduan tidak dicabut atau dibatalkan oleh pengadunya maka Komnas HAM akan memprosesnya sesuai prosedur yang berlaku di Komnas HAM. Tetapi jika pengaduan dibatalkan sepihak oleh si pengadu, maka yang bersangkutan harus membuat surat pembatalan atau pencabutan pengaduan secara tertulis. ${ }^{10}$

\footnotetext{
${ }^{7}$ Tim Penyusun Revisi Naskah Komprehensif, Perubahan Undang-Undang Dasar Negara Republik Indonesia Tahun 1945, Latar Belakang, Proses, dan Hasil Pembahasan 1999-2002, Buku VIII Warga Negara dan Penduduk, Hak Asasi Manusia, dan Agama, (Jakarta: Sekretariat Jenderal dan Kepaniteraan Mahkamah Konstitusi, 2010), hlm. 2425.

${ }^{8}$ Ibid., hlm. 25

9 A. Bazar Harahap dan Nawangsih Sutardi, Op. Cit., hlm. 6.

10 Eko Riyadi dan Supriyanto Abdi (Editor), Op. Cit., hlm. 188.
}

\section{B. METODE PENELITIAN}

Berdasarkan uraian tersebut di atas, dirumuskan persoalan dalam lingkup kajian terhadap hak atas kebebasan beragama dan berkeyakinan serta hak atas pekerjaan. Penelitian ini menggunakan jenis atau tipe penelitian hukum normatif. Dalam aspek metode pengumpulan data, metode yang dilakukan adalah studi kepustakaan. Analisis data dalam penelitian ini dilakukan secara sistematis berdasarkan rumusan permasalahan penelitian yang diuraikan secara kualitatif.

\section{PEMBAHASAN}

\section{Kajian terhadap Hak atas Kebebasan Beragama dan Berkeyakinan}

Kajian terhadap hak atas kebebasan beragama dan berkeyakinan memiliki aspek (ruang lingkup) yang luas ${ }^{11}$. Oleh

11 Salah satu tinjauan terkait aspek kebebasan beragama adalah sebagaimana yang telah dilakukan kajian oleh Stephanus Tilung Arifin dengan salah satu kesimpulan sebagai berikut: Dalam pasal-pasal tentang Hak Asasi Manusia dalam UUD NRI tahun 1945 dengan tegas diatur bahwa beragama adalah hak asasi manusia. Walaupun dalam peraturan perundangan masih terdapat tumpang tindih dan kesemerawutan aturan hukum yang justeru dapat membahayakan kehidupan beragama, namun usahausaha baik pengkajian maupun pengajuan ke Mahkamah Konstitusi untuk membatalkan, atau merevisi beberapa peraturan perundang-undangan sebagai politik hukum kehidupan beragama di waktuwaktu yang akan datang Nampak jelas dari waktu ke waktu. Putusan Mahkamah Konstitusi Nomor 140/ PUU-VII/2009 tentang Penolakan Pengujian UU No. 1/PNPS/1965 tentang Pencegahan Penyalahgunaan dan/atau Penodaan Agama memberikan pemahaman mendasar tentang kebebasan beragama di Indonesia, yaitu: Pemberlakuan UU No. 1/PNPS/1965 secara yuridis formil memang tidak bertentangan dengan UUD 1945 meskipun dibentuk pada masa demokrasi terpimpin. Hal tersebut diperkuat dari sisi materiil, UU No. 1/PNPS/1965 yang memberikan pengaturan tambahan tentang kejahatan terhadap agama yang tekait dengan forum externum, yaitu misalnya pembubaran organisasi keagamaan, pelanggaran organisasi aliran kepercayaan, penyegelan rumah ibadah, penutupan lembaga keagamaan, pelarangan 
karena itu, dalam penelitian ini, kajian tersebut dibatasi terhadap pentingnya regulasi oleh pembentuk undang-undang dalam mengatur peran dan pemberian sanksi bagi pemerintah dalam konteks (ruang lingkup) terjaminnya kebebasan beragama $^{12}$ dan berkeyakinan di Indonesia, khususnya terhadap penganut agama Islam (yang mayoritas) di Indonesia.

Menurut penulis, Allah subhanahu wata'ala telah menegaskan Islam sebagai satu-satunya agama yang benar, yang bertujuan untuk menyelamatkan manusia sehingga terdapat aturan khusus bagi pemeluk agama Islam yang murtad.

Murtad adalah keluarnya seseorang dari agama Islam dan memeluk agama lain atas kehendaknya sendiri dan tanpa paksaan siapapun. Berdasarkan penjelasan Hadis-Hadis Nabi SAW., tentang hukuman bagi orang yang murtad, dengan tegas dikatakan bahwa pelaku murtad dijatuhi hukuman mati, dan Jumhur ulama sepakat akan hal ini. Dalam Al-Qur'an, Allah SWT., dengan jelas mengatakan bahwa orang yang keluar dari agama Islam/murtad akan

kegiatan keagamaan, diskriminasi pelayanan publik dan sebagainya. Terdapat tiga bentuk kejahatan terhadap agama di dalam UU No. 1/PNPS/1965 yaitu kejahatan penyimpangan ajaran agama, kejahatan terhadap ajaran agama, dan kejahatan untuk tidak beragama. Pengkajian sekaligus perumusan kejahatan terhadap agama perlu lebih lanjut dikembangkan agar tidak disalahgunakan oleh pihak-pihak yang ingin menghambat kebebasan beragama. Selengkapnya lihat: Stephanus Tilung Arifin, "Proses Hukum bagi Pelaku Kejahatan Penodaan Agama dalam Hubungannya dengan Kebebasan Beragama menurut Hak Asasi Manusia di Indonesia", Lex et Societatis, Vol. IV/No. 4/Apr/2016, hlm. 69-70.

12 Nabi Muhammad sejak awal sudah mengimplementasikan prinsip kebebasan beragama dalam wujud prinsip persamaan dan penghormatan kepada manusia dalam masyarakat Madinah yang sangat heterogen sebagaimana tertuang dalam piagam Madinah. Selengkapnya lihat: Muhammad Zaini, "Hak Asasi Manusia menurut Al-Qur'an dan Hadis Nabi Saw", Al-Mu'ashirah Vol. 13, No. 1, Januari 2016, hlm. 11. dihukum dengan azab yang sangat pedih dan ditempatkan di neraka jahannam. Di Indonesia, berdasarkan informasi dan pemberitaan, banyak umat Islam yang keluar dari agamanya dan memeluk agama lain dengan berbagai macam motif dan alasan yang berbeda-beda tergantung pada kepentingannya masingmasing. Fenomena ini tampaknya menjadi trend baru dan menjadi sebuah gaya hidup atau lifestyle di tengah derasnya arus globalisasi, kehidupan berdemokrasi, penghormatan terhadap hak asasi manusia dan kebebasan beragama yang tengah diperjuangkan oleh segelintir orang untuk membawa misi-misi tertentu dalam rangka merealisasikan misi dan isu global. Oleh karena itu, bagi pelaku murtad tidak dijatuhi hukuman atau sanksi apapun kecuali sanksi moral dan sanksi sosial, karena negara Indonesia tidak berlandaskan pada hukum Islam yang bersumber dari Al-Qur`an dan Hadis Nabi. ${ }^{13}$

Berdasarkan uraian di atas, dapat dikatakan bahwa terdapat kekosongan hukum dalam regulasi kebebasan beragama di Indonesia dalam konteks keluarnya seseorang dari agama Islam (tentu juga bagi pemeluk agama lainnya di Indonesia) dan memeluk agama lain atas kehendaknya sendiri dan tanpa paksaan siapapun.

Prinsip kebebasan beragama, yang merupakan prinsip dasar ajaran Islam, tidak mungkin di-nasakh karena bersifat tetap dan universal. Memegang teguh prinsip ini sangat berdampak positif pada perubahan paradigma hukum murtad serta kehidupan keagamaan umat Muslim. Setiap pemeluk agama bebas memilih keyakinannya dan menunaikan ibadahnya sesuai dengan keyakinan

\footnotetext{
${ }^{13}$ Muhammad Mutawali, "Murtad: Antara Hukuman Mati dan Kebebasan Beragama", (2017, October 28), diakses tanggal 17 Desember 2018, doi: https://doi.org/10.31219/osf.io/dgaxk.
} 
masing-masing. Masyarakat, dengan demikian, mampu hidup berdampingan, damai dan saling menghormati. ${ }^{14}$

Prinsip kebebasan beragama dijamin oleh al-Quran. Dalam hal ini seseorang dapat saja berpindah murtad atau pindah ke agama lain. ${ }^{15}$ Berdasarkan hal ini, diuraikan tinjauan lainnya dalam konteks kebebasan beragama di Indonesia.

a) Kebebasan untuk Memeluk Agama

Hingga kini Indonesia telah diperintah berdasarkan 7 konstitusi. Selama 1999-2002 MPR telah mengubah UUD 1945 dengan menggunakan metode amandemen dan teknik addendum. Hasil perubahan formal diwujudkan dalam empat dokumen perubahan yang antara lain mengenai kedaulatan, negara hukum, wewenang MPR/DPD, masa jabatan presiden, pencantuman hak asasi manusia termasuk hak atas pendidikan, dan rumusan baru tentang pertahanan dan keamanan. ${ }^{16}$

Materi konstitusi mungkin ditentukan tidak hanya organ dan

\footnotetext{
${ }^{14}$ Moh Abdul Kholiq Hasan, "Ayat-ayat Kebebasan Beragama dalam Perspektif Nasakh: Kajian terhadap Penafsiran Ibn Kathîr dan Rashîd Ridâ", Mutawâtir: Jurnal Keilmuan Tafsir Hadis Volume 6, Nomor 2, Desember 2016, hlm. 310.

15 Jimly Asshiddiqie, Konstitusi dan Konstitusionalisme Indonesia, (Jakarta: Konstitusi Press, 2005), hlm. 78. Ajaran dasar al-Qur'an mengenai kebebasan beragama seakan terciderai oleh adanya ketetapan hukuman mati bagi orang yang keluar dari Islam (murtad). Terlebih lagi seringkali ketetapan hukuman mati disalahgunakan oleh pemegang kekuasaan untuk menyingkirkan lawanlawan politik, atau vonis murtad dijatuhkan secara "semena-mena" untuk membungkam nalar kritis dalam beragama. Selengkapnya lihat: Mahmud Arif, "Islam Humanis, HAM, dan Humanisasi Pendidikan: Eksposisi Integratif Prinsip Dasar Islam, Kebebasan Beragama, Kesetaraan Gender, dan Pendidikan Humanis", Musâwa, Vol. 15 No. 2 Juli 2016, hlm. 236.

16 A. Patra M. Zen dan Daniel Hutagalung (Editor), Panduan Bantuan Hukum di Indonesia: Pedoman Anda Memahami dan Menyelesaikan Masalah Hukum, (Jakarta: YLBHI, 2006), hlm. 314.
}

prosedur legislasi, tetapi juga pada tingkat tertentu isi dari hukum yang akan datang. Konstitusi dapat menentukan secara negatif apa materi yang dilarang sebagai isi hukum, misalnya parlemen dilarang menyetujui setiap rancangan undangundang yang membatasi kebebasan beragama. Dengan cara negatif ini, tidak hanya isi undang-undang tetapi juga semua norma dari tata hukum ditentukan oleh konstitusi. Konstitusi juga dapat menentukan secara positif isi tertentu dari undang-undang yang akan datang baik berupa materi delik, sanksi, maupun prosedur. ${ }^{17}$

Jaminan kebebasan beragama dan menjalankan ibadat, dalam Pasal 29 UUD 1945 kiranya dipahami dan diterapkan dalam kerangka holistik dan humanistis, sebab pasal ini termasuk salah satu pasal yang rawan dalam sistem demokrasi Indonesia. Selama belum ditemukan tafsiran yang jelas akan dengan mudah oknum-oknum tertentu mengklaim tindakan keagamaan sebagian orang atau kelompok sebagai ekstrim, tidak Pancasilais dan dianggap akan membangun kembali reruntuhanreruntuhan Piagam Jakarta menuju ke arah pembentukan negara Islam, dan lain sebagainya. ${ }^{18}$

Konsepsi kembali kepada UUD 1945 serta tekad unfuk menjalankan dan mengamalkan Pancasila secara murni dan konsekuen adalah sebagai doktrin Pemerintah Orde Baru. Maka dengan Pancasila sebagai landasan idiil dan UUD 1945 sebagai landasan konstitusionil, negara Indonesia akan terlepas dari pengaruh faham kapitalis,

17 Jimly Asshiddiqie dan M. Ali Safa'at, Teori Hans Kelsen tentang Hukum, (Jakarta: Sekretariat Jenderal dan Kepaniteraan Mahkamah Konstitusi RI, 2006), hlm. 112.

18 Jazim Hamidy dan M. Husnu Abadi, Op. Cit., hlm. 242. 
sosialis maupun komunis. ${ }^{19}$ Salah satu aspek HAM yang senantiasa dirumuskan dalam setiap konstitusi dan dokumen deklarasi adalah

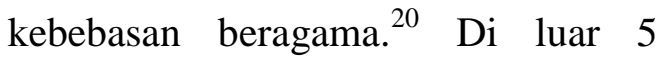
agama yang resmi, tetap memperoleh perlindungan. $^{21}$

Perlindungan hukum yang diberikan Pasal 1 UU Nomor 1/PnPs/1965 terhadap agama (larangan terhadap penafsiran dan kegiatan yang "menyimpang dari pokok-pokok ajaran agama itu") yang dianut di Indonesia merupakan bagian yang tidak terpisahkan dari perlindungan terhadap hak atas kebebasan beragama. Perlindungan hukum terhadap agama ini tidaklah bertentangan sama sekali dengan hak atas kebebasan beragama yang telah dijamin oleh UUD NRI 1945, tetapi justru merupakan bagian dari kewenangan konstitusional negara untuk melindungi kebebasan beragama itu sendiri. $^{22}$

Berdasarkan uraian di atas, diketahui bahwa jaminan terhadap kebebasan beragama dalam konsitusi di Indonesia, telah diakomodir dengan baik. Selanjutnya, di bawah ini diuraikan kasus-kasus penting, yaitu aliran keagamaan sesat dalam agama Islam dan kasus ahmadiyah.

Berdasarkan hasil temuan-temuan The Wahid Institute terkait dengan kebebasan beragama dan intoleransi 2012, disebutkan beberapa hal, yaitu sebagai berikut:

a. Meningkatnya pelanggaran kebebasan beragama yang melibatkan aparat negara

19 Ibid., hlm. 6.

20 Jazim Hamidy dan M. Husnu Abadi, Op. Cit., hlm. 7-8.

21 Ibid., hlm. 8 .

22 Adam Muhshi, "Teologi Konstitusi: Hukum Hak Asasi Manusia atas Kebebasan Beragama di Indonesia", Yogyakarta: Lkis Pelangi Aksara, 2015, hlm. 190. memperlihatkan bahwa trend pengelolaan hak-hak beragama di Indonesia cenderung bercorak membatasi ketimbang menjamin dan melindungi. Ketika terjadi konflik antara mayoritas dan minoritas agama misalnya, negara seringkali membatasi hak kelompok minoritas dengan alasan menghindari konflik yang lebih besar. Pendekatan menghindari konflik ini jelas bertentangan dengan kewajiban negara untuk menjamin hak setiap warga negara untuk beragama dan beribadah menurut keyakinannya.

b. Polisi sebagai penegak hukum di lapangan terlibat paling sering dalam berbagai pelanggaran kebebasan beragama. Padahal polisi telah memiliki satu landasan hukum sebagai pegangan dalam menangani pelanggaran HAM dan perlindunga minoritas yakni Perkap No. 8 tahun 2009. Perkap ini belum mampu dijalankan secara konsisten di lapangan.

c. Selain itu, dengan desentralisasi urusan agama ini, jaminan kebebasan beragama sekaligus mengalami pelemahan. Karena apabila pada level tertinggi seperti konstitusi, jaminan kebebasan beragama sangat kuat, ketika pengaturan itu dilakukan oleh institusi pemerintah pada level daerah seperti kabupaten, kecamatan hingga desa, justru derajat perlindungannya semakin rendah.

d. Kelompok terduga sesat akan menjadi korban tertinggi apabila JAI dan Syiah juga 
dimasukkan. Fakta ini menunjukkan bahwa umat Kristen dan kelompok terduga sesat adalah entitas yang paling rentan terhadap pelanggaran. Apabila dikaitkan dengan pelaku pelanggaran, maka polisi, Satpol PP dan Pemerintah Daerah menjadikan umat Kristen dan kelompok terduga sesat sebagai sasaran utama pembatasan.

e. Apabila melihat angka-angka tindakan pelanggaran kebebasan beragama oleh aktor non-negara juga mengindikasikan bahwa penyebaran gagasan dan prilaku intoleransi di masyarakat semakin luas, sementara di sisi lain mainstreaming toleransi justru tersendat atau bahkan gagal.

f. Peningkatan ini juga dapat disebabkan oleh semakin rendahnya dukungan terhadap uyapa-upaya menyebarkan gagasan toleransi dan menghargai keragaman di masyarakat. Tema-tema toleransi dan kebebasan beragama sekain terpinggirkan atau dengan kata lain isu toleransi dan kebebasan beragama saat ini menjadi isu pinggiran.

g. FPI masih menjadi kelompok ormas yang paling banyak melakukan tindakan intoleransi. Dalam hal ini aparat penegak hukum di lapangan tidak mampu menegakkan wibawa mereka di hadapan ormasormas pelaku kekerasan seperti FPI.

h. Program pemerintah mempromosikan dan mendorong kerukunan terlihat kurang efektif, tidak hanya tahun ini tetapi juga pada tahuntahun sebelumnya. Programprogram tersebut tidak mampu menyentuh akar persoalan intoleransi yakni sikap konservatisme dan fanatisme yang berlebihan menghadapi perbedaan di masyarakat.

i. Dari temuan terkait regulasi agama di berbagai daerah menunjukkan bahwa trend formalisasi syariat Islam di Indonesia kembali menguat setelah meredup beberapa tahun sebelumnya. Pergub Jawa Timur mengenai pengawasan aliran sesat atau rencana Polisi Syariah di Tasikmalaya adalah ide-ide formalisasi syariat Islam yang sangat mengancam hakhak sipil warga negara terutama hak beragama.

j. Munculnya berbagai regulasi diskriminatif dan melanggar hak-hak beragama di berbagai daerah ini memperlihatkan bahwa politik desentralisasi telah membuka peluang sebesar-besarnya bagi berkembangnya politik aliran di level daerah. Pemerintah pusat tidak mampu menegakkan aturan yang menegaskan bahwa masalah agama tetap menjadi kewenangan pusat, karena para elit daerah mengklaim pengelolaan isu agama didaerah sebagai bagian dari pengaturan ketertiban umum. Karena itu tidak heran dalam banyak kasus bernuansa agama, Pemerintah Pusat lepas tangan dan justru menyerahkan penyelesaiannya kepada Pemerintah Daerah.

k. Jawa Barat lagi-lagi menjadi daerah dengan tingkat pelanggaran kebebasan 
beragama dan intoleransi tertinggi. Bila dibanding tahuntahun sebelumnya, Jawa Barat terus mengalami peningkatan jumlah kasus. Tren peningkatan ini menunjukkan bahwa konservatisme keagamaan di daerah ini terus mengalami pertumbuhan. Sikap konservatisme ini beriringan dengan sikap eksklusif dan intoleran.

1. Namun demikian, sikap konservatisme ini bukan satusatunya sebab mengapa Jawa Barat menjadi daerah dengan tingkat pelanggaran dan intoleransi tertinggi. Dalam banyak kasus pelanggaran dan intoleransi beragama di Jawa Barat, juga sering merupakan akibat dari maraknya politisasi isu agama oleh para elit lokal. Banyak ditemukan kasus-kasus intoleransi di beberapa kabupaten/kota muncul justru menjelang perhelatan Pilkada. Dalam kasus politisasi agama ini, isu Ahmadiyah dan rumah ibadah umat Kristen paling banyak muncul.

m. Dalam kasus pendirian Masjid di Batuplat NTT, pelanggaran hak-hak beragama dan ketidakpastian hukum bagi minoritas muslim di sana terus berlangsung hingga saat ini. Masjid ini telah memiliki IMB dan telah melaksanakan peletakan batu pertama, namun proses pembangunannya tidak bisa dilanjutkan karena sejumlah warga mayoritas nonmuslim yang sebelumnya mendukung menarik dukungannya. Pemerintah setempat juga cenderung membiarkan penyelesaian persoalan tersebut.

n. Dalam kasus pelarangan GKI Yasmin di Bogor, sorotan dan kritik tidak hanya datang dari dalam negeri, namun juga dari dunia internasional. Namun sorotan dan kritik tersebut tidak membantu penyelesaian di dalam negeri.

o. Selain meningkatnya pelanggaran kebebasan beragama dan intoleransi, juga terdapat sejumlah kemajuan dalam jaminan kebebasan beragama dan toleransi di masyarakat. Kemajuankemajuan tersebut harus tetap diapresaisi dan dicatat sebagai prestasi bangsa Indonesia secara keseluruhan. Dimana ditengah maraknya pelanggaran kebebasan beragama dan intoleransi, masih tetap ada upaya-upaya serius untuk melindungi dan menghargai perbedaan di masyarakat. $^{23}$

Berdasarkan hasil temuan tersebut di atas, The Wahid Institute merekomendasikan hal-hal yang terkait dengan kebebasan beragama dan intoleransi, yaitu:

a. Mendesak pemerintah untuk segera melaksanakan rekomendasi, terutama menyangkut praktik kebebasan beragama, perlindungan terhadap hak kelompok minoritas di Indonesia.

b. Mendesak pemerintah untuk mengevaluasi pelaksanaan Peraturan Bersama Menteri (PBM) tahun 2006 tentang rumah ibadah karena sudah tidak

23 Laporan The Wahid Institute: Ringkasan Eksekutif Laporan Akhir Tahun Kebebasan Beragama dan Intoleransi 2012, Kerjasama The Wahid Institute dan Yayasan Tifa, hlm. 14-17. 
efektif lagi menjembatani konflik-konflik rumah ibadah.

c. Mendesak agar berbagai aturan baik di tingkat pusat maupun daerah yang diskriminatif atau bahkan melanggar hak-hak beragama agar dievaluasi dan bila terbukti melanggar konstitusi agar segera dibatalkan.

d. Meminta agar pengaturan diskriminatif mengenai agama oleh pemerintah baik pusat maupun daerah harus segera dihentikan karena selain merupakan bentuk intervensi negara terhadap persoalan agama warga negara, berbagai regulasi tersebut telah meningkatkan ketegangan antar pemeluk agama di daerah. Pemerintah harus menolak atau membekukan berlakunya peraturan daerah yang diskriminatif ini.

e. Dalam rangka penertiban regulasi daerah yang diskriminatif ini, Pemerintah Pusat dapat membatalkan Peraturan Daerah dan Keputusan Kepala Daerah yang bertentangan.

f. Jika dimungkinkan ada mekanisme peradilan yang fair terhadap Ormas-ormas tersebut guna memberi sanksi terhadap organisasi seperti denda atau pembubaran (bukan perorangan seperti yang ada selama ini).

g. Pemerintah perlu membuat indikator pertumbuhan di bidang sosial dan budaya khususnya dalam bidang kebebasan beragama dan toleransi, sehingga dapat menentukan model penyelesaian yang efektif.

h. Mendesak kepada ormas-ormas keagamaan moderat mengeluarkan surat edaran kepada pengikutnya untuk tidak melakukan kekerasan kepada kelompok minoritas sembari mendorong dialog-dialog yang produktif membangun toleransi dan menghormati perbedaan. ${ }^{24}$

\section{b) Kebebasan untuk Beribadah}

Salah satu bentuk campur tangan negara dalam bidang keagamaan adalah memenuhi kebutuhan dan memberikan fasilitas yang diperlukan agar rakyat Indonesia dapat secara penuh memeluk dan mengamalkan ajaran agamanya. Perlindungan dan kewenangan ini memang dimaksudkan agar umat beragama dapat memeluk dan beribadat secara tentram dan penuh kedamaian. ${ }^{25}$

Menurut Jazim Hamidi dan M. Husnu Abadi, salah satu bentuk campur tangan negara pada rakyat dalam bidang keagamaan adalah memenuhi kebutuhan dan memberikan fasilitas yang diperlukan agar rakyat Indonesia dapat secara penuh memeluk dan mengamalkan ajaran agamanya. Perlindungan dan kewenangan ini memang dimaksudkan agar umat beragama dapat memeluk dan beribadat secara tentram dan penuh kedamaian. ${ }^{26}$

Potret kebebasan beragama di Indonesia sesungguhnya sudah berkembang sejak bangsa ini akan diproklamirkan tahun 1945 silam, bahkan jauh sebelum itu. Melalui BPUPKI, wacana ini hangat diperdebatkan founding father khususnya dalam perumusan Pasal 29 UUD 1945. Kebebasan beragama (bebas berkeyakinan) merupakan hak setiap manusia dan pada dasarnya HAM tidak

24 Ibid., hlm. 17-18.

25 Tim Penyusun Revisi Naskah Komprehensif, Loc. Cit., hlm. 8.

${ }^{26}$ Jazim Hamidi dan M. Husnu Abadi, Intervensi Negara Terhadap Agama: Studi Konvergensi atas Politik Aliran Keagamaan dan Reposisi Peradilan Agama di Indonesia, (Yogyakarta: UII Press, 2001), hlm. 8 . 
dapat dibatasi atau dilanggar. Akan tetapi, dalam kasus-kasus tertentu HAM dapat dibatasi asalkan dapat diatur dalam undang-undang dengan bertujuan semata-mata hanya untuk menjamin agar HAM orang lain dihormati dan tidak dilanggar. Di Indonesia dalam pelaksanaannya HAM tidak boleh merugikan sesama dalam masyarakat. ${ }^{27}$

Selama belum ditemukan tafsiran yang jelas akan dengan mudah oknumoknum tertentu mengklaim tindakan keagamaan sebagian orang atau kelompok sebagai ekstrim, tidak Pancasilais dan dianggap akan membangun kembali reruntuhanreruntuhan Piagam Jakarta menuju ke arah pembentukan negara Islam, dan lain sebagainya. Kuntowijoyo sebagai budayawan sejak dini telah mengingatkan dan mengajak semua pihak untuk memahami bagaimana Islam telah di-Indonesia-kan sejak Islam datang di negeri ini, bukan seperti pemahaman sementara kalangan bagaimana mengIndonesia-kan Islam. Pendapat yang kedua ini justru yang akan mengaburkan pemahaman keagamaan atau lebih dari itu akan memojokkan umat Islam di lndonesia. ${ }^{28}$

\section{c) Kebebasan Menyiarkan Agama}

Kebebasan untuk memeluk agama di Indonesia dijamin karena kebebasan. ${ }^{29}$ Terkait dengan penghormatan terhadap agama Ranuwihardjo berpendapat sebagai berikut: Terhadap kebebasan beragama, dapat ditambahkan hak

27 M. Anwar Nawawi, "Kebebasan Beragama di Indonesia (Studi Jemaat Ahmadiyah dalam Perspektif Majelis Ulama Indonesia dan Komisi Nasional Hak Asasi Manusia)", Fikri, Vol. 3, No. 1, Juni 2018, hlm. 214.

28 Jazim Hamidy dan M. Husnu Abadi, Op. Cit., hlm. 242.

29 Bagir Manan, Perkembangan Pemikiran dan Pengaturan Hak Asasi Manusia di Indonesia, (Jakarta: Yayasan Hak Asasi Manusia, Demokrasi dan Supremasi Hukum, Alumni, 2006), hlm. 121122 kehormatan bagi agama atau sesembahan seseorang yaitu berdasarkan perintah AlQur'an yang mengandung larangan bagi muslim/muslimat memaki atau menjelekjelekkan agama lain. Perintah ini mengandung implikasi larangan untuk propaganda anti agama, sebagaimana yang pernah dipraktekkan oleh negaranegara komunis, karena dalam propaganda anti agama itu, agama-agama dijelek-jelekkan. Implikasi lebih lanjut dari perintah Al-Qur'an untuk tidak mengolok-olok agama lain ialah bahwa kebebasan beragama tidak mengandung kebebasan anti agama. Dari kebebasan beragama itu timbullah pula hak untuk mendirikan tempat-tempat ibadah serta tempat-tempat pendidikan agama dan lebih lanjut menimbulkan kebebasan untuk mendirikan organisasi-organisasi beragama. Kebebasan beragama itu mengandung pula kebebasan untuk menganut agama sempalan yaitu aliran agama yang menyimpang dari the mainstream, yaitu aliran agama yang dianut oleh mayoritas pemeluknya. Golongan agama yang disebut the mainstream, tidak berhak meminta kepada pemerintah atau kepada yang berwajib untuk melarang aliran sempalan. Baru kalau sesuatu aliran sempalan melakukan kegiatan yang mengganggu keamanan dan ketertiban, yang berwajib dapat menindaknya. Alasan tindakan ini bukan karena nyempal-nya, melainkan karena gangguannya terhadap keamanan dan ketertiban. $^{30}$

\section{d) Kebebasan Mendirikan Rumah Ibadah}

Salah satu bentuk campur tangan negara pada rakyat dalam bidang keagamaan adalah memenuhi kebutuhan dan memberikan fasilitas yang diperlukan agar rakyat Indonesia dapat secara penuh memeluk dan

30 Tim Penyusun Revisi Naskah Komprehensif, Loc. Cit., hlm. 372. 
mengamalkan ajaran agamanya. Perlindungan dan kewenangan ini memang dimaksudkan agar umat beragama dapat memeluk dan beribadat secara tentram dan penuh kedamaian. ${ }^{31}$

\section{e) Kebebasan Memilih Aliran- aliran/Sekte-sekte dalam Suatu Agama}

Banyaknya aliran-aliran keagamaan (Islam) yang isinya tidak hanya mempunyai perbedaan di bidang pokokpokok ajaran agama bahkan pada beberapa aliran keagamaan ada yang mempunyai ajaran yang dinyatakan kafir kepada mereka yang tidak bersedia mengikuti alirannya. Di samping itu juga ada aliran-aliran yang mempunyai pendirian yang menyatakan keharusan membunuh mereka yang tidak sealiran. Meskipun demikian, terdapat juga banyak mazhab dan aliran-aliran keagamaan atau ataupun sekte yang mempunyai perbedaan ajaran pokoknya, tetapi mempunyai prinsip toleransi terhadap pemeluk agama lainnya atau penganut aliran keagamaan lainnya. Perbedaan pokok tersebut dapat menyangkut masalah kedudukan pemimpin aliran, seperti aliran Ahmadiyah yang menganggap pemimpinnya sebagai nabi. Demikian juga suatu aliran yang menempatkan para imam tertentu sebagai pemimpin/imam yang amat mulia dan pendapatpendapatnya memperoleh tempat yang khusus di antara penganut-penganutnya, seperti aliran Syiah. ${ }^{32}$

Di Indonesia seringkali lahir aliran keagamaan yang oleh para ulama dinilai dan dinyatakan sesat dan pada langkah selanjutnya oleh negara dibubarkan dan dinyatakan terlarang. Hal ini antara lain dialami oleh aliran Islam Jamaah, Inkarussunnah ataupun aliran Lemkari (Lembaga Karyawan Dakwah Islam). Aliran keagamaan yang dianut LDII kini

\footnotetext{
31 Ibid., hlm. 8.
}

32 Ibid., hlm. 8-9. dapat meneruskan kegiatannya setelah mengalami perubahan-perubahan, baik yang berkenaan dengan ajarannya maupun organisasinya. Corak lain dari aliran keagamaan yang kegiatannya oleh Pemerintah RI dinyatakan sesat dan dilarang adalah aliran yang menempatkan pemimpinnya sebagai nabi dan mengubah kalimat syahadat. Ini terlihat dari aliran yang bernama Waiya Kanasatain, dipimpin oleh Ajis Muliadin, di Sukabumi, Jawa Barat. Suatu aliran keagamaan juga dinilai dari aspek peribadatannya. Bila perbedaannya tidak masuk akal dan tidak ada tuntunan dari agama, maka aliran keagamaan itu dapat dilarang. Hal ini terjadi pada aliran yang menamakan dirinya Islam Sejati di Lampung Selatan yang mengajarkan sholat berjamaah dengan kondisi kesurupan. ${ }^{33}$

Banyaknya aliran-aliran keagamaan (Islam) yang isinya tidak hanya mempunyai perbedaan di bidang pokokpokok ajaran agama bahkan pada beberapa aliran keagamaan ada yang mempunyai ajaran yang dinyatakan kafir kepada mereka yang tidak bersedia mengikuti alirannya. Di samping itu juga ada aliran-aliran yang mempunyai pendirian yang menyatakan keharusan membunuh mereka yang tidak sealiran. Meskipun demikian, terdapat juga banyak mazhab dan aliran-aliran keagamaan atau ataupun sekte yang mempunyai perbedaan ajaran pokoknya, tetapi mempunyai prinsip toleransi terhadap pemeluk agama lainnya atau penganut aliran keagamaan lainnya. Perbedaan pokok tersebut dapat menyangkut masalah kedudukan pemimpin aliran, seperti aliran Ahmadiyah yang menganggap pemimpinnya sebagai nabi. Demikian juga suatu aliran yang menempatkan para imam tertentu sebagai pemimpin/imam

33 Ibid., hlm. 9. 
yang amat mulia dan pendapatpendapatnya memperoleh tempat yang khusus di antara penganut-penganutnya, seperti aliran Syiah. ${ }^{34}$

Hasil survei LSI memperlihatkan makin tingginya tingkat intoleransi beragama di kalangan masyarakat. Dalam survei ini, LSI mengambil dua isu mutakhir: kekerasan terhadap penganut Ahmadiyah dan pendirian rumah ibadah. Berkaitan dengan Ahmadiyah, hasil survei memperlihatkan pembenaran terhadap kekerasan pada warga Ahmadiyah makin tinggi. Jika pada tahun 2005, jumlah warga yang setuju dengan tindakan kekerasan pada Ahmadiyah hanya $13,9 \%$, pada tahun 2010 ini angkanya naik menjadi 30,2\%. Jumlah warga yang setuju apabila pemerintah melarang ajaran Ahmadiyah di Indonesia juga makin tinggi. Pada tahun 2005, jumlah mereka yang setuju jikalau pemerintah melarang Ahmadiyah hanya 35,2\%. Saat ini di tahun 2010 jumlahnya naik menjadi $53,4 \%$. Data ini memperlihatkan penghormatan terhadap warga yang mempunyai keyakinan berbeda, makin menurun. Masalah kebebasan beragama lain yang harus diwaspadai adalah konflik dalam pendirian tempat ibadah. Secara umum, survei LSI ini memang memperlihatkan publik merasa pendirian tenpat ibadah selama ini mudah. Tetapi jika dilihat warga berdasarkan agama (terutama Islam dan Kristen) terdapat perbedaan yang mencolok. Di kalangan warga Islam, pendirian masjid dan gereja secara umum dinilai mudah. Sebaliknya, bagi warga Kristen, dalam jumlah besar $(40,8 \%)$ merasa bahwa pendirian gereja selama ini sulit. Data survei ini memperlihatkan adanya ketidakpuasan di kalangan warga Kristen berkaitan dengan kebebasan dalam mendirikan rumah ibadah. Salah satu alasan mengapa

34 Ibid., hlm. 8-9. intoleransi agama makin menurun dan aksi kekerasan atas nama agama makin tinggi adalah kurang tegasnya sikap pemerintah. Selama ini pemerintah kurang bersikap tegas terhadap aksi kekerasan yang dilakukan atas nama agama. Dalam kasus kekerasan pada warga Ahmadiyah misalnya. Aparat tidak menjaga kesalamatan warga Ahmadiyah sehingga aksi kekerasan tetap berlangsung. Lebih jauh dari itu, pemerintah tidak secara tegas mengkritik aksi kekerasan pada warga yang berbeda keyakinan. Dengan sikap tegas pemerintah, kebebasan warga dalam beribadah dapat terus dijamin. Dan keyakinan warga untuk beribadah dan menjalankan keyakinannya bisa terus dipupuk. $^{35}$

Hak-hak kebebasan beragama dan berkeyakinan dijamin dalam UUD 1945. Sementara pemerintah telah mengeluarkan kebijakan-kebijakan yang bersifat diskriminatif mencakup SKB Tiga Menteri Tahun 2008 tentang Ahmadiyah, Peraturan Bersama Dua Menteri Tahun 2006 tentang Pendirian Rumah Ibadah, dan UU No. 1/PNPS/1965 tentang Penodaan Agama. Termasuk berbagai peraturan daerah tentang pembatasan kegiatan Ahmadiyah. Kebijakan-kebijakan pemerintahan yang diskriminatif merupakan bentuk negasi dari hak-hak kebebasan beragama dan berkeyakinan yang dijamin dalam UUD 1945. Oleh karena itu, pemerintah harus memandang serius dan bersikap integral dengan UUD 1945 sebagai norma dasar negara (norma yang melandasi pelaksanaan kebijakan negara). ${ }^{36}$

35 Lingkaran Survei Indonesia, Meningkatkan Intoleransi Beragama Masyarakat Indonesia, Kajian Bulanan Edisi No. 23, Oktober 2010, hlm. 1.

36 Dedi Putra, "Membangun Kembali Nilai-nilai Dasar Keislaman sebagai Resolusi Konflik Ahmadiyah: Diskursus Hak Kebebasan Beragama dan Berkeyakinan", Ri'ayah, Vol. 02, No. 01 Januari-Juni 2017, hlm. 154. 
Indonesia telah menjamin hak dan kebebasan setiap warganya untuk beragama sesuai keyakinannya sendiri. Oleh karena itu, maka selayaknyalah orang-orang yang duduk di legislatif dan eksekutif untuk senantiasa menjaga kebebasan beragama setiap warganya tersebut tanpa melihat ideologi yang dianutnya. Untuk menghapus praktikpraktik diskriminatif dan ketidakadilan, maka diperlukan dua jalur upaya sekaligus; perjuangan politik kesetaraan dan penguatan kapasitas dan pemahaman multikulturalisme atas nilai-nilai demokrasi. Upaya pertama merupakan advokasi atas sejumlah kebijakan negara yang masih dirasa belum adil. Beberapa produk undang-undang yang kurang selaras dengan semangat UUD 1945 dan perkembangan dunia modern sudah selayaknya ditinjau kembali. Sedangkan upaya kedua dimaksudkan untuk memperkuat kesadaran umat mayoritas untuk lebih mengembangkan nilai-nilai kesetaraan, kebebasan, humanistik, cinta tanah air dan toleransi terhadap keragaman. Apabila hal-hal mulia ini berhasil dikembangkan dan diimplementasikan oleh seluruh umat maka akan bermanfaat tidak hanya bagi konsolidasi, tetapi juga akan semakin meneguhkan bangsa dan Negara. ${ }^{37}$

Dinamika praksis kebebasan beragama di Indonesia pada rentang 1998-2011 secara umum dipenuhi oleh aneka bentuk pelanggaran dengan eskalasi yang cenderung meningkat dari tahun ke tahun. Inkonsistensi negara dalam memproduksi aturan dan lemahnya law enforcement serta menguatnya trend keberagamaan berspirit islamisme di tengah masyarakat pasca-Orde Baru telah bersumbangsih besar bagi eskalasi

37 Irfan Setia Permana, "Pemerintah dan Hak Beragama di Indonesia (Peran Pemerintah dalam Memelihara Hak Beragama di Indonesia)", TEDC Vol. 12 No. 2, Mei 2018, hlm. 131. tersebut. ${ }^{38}$ Oleh karena itu, konsep kebebasan beragama yang dideklarasikan oleh Perserikatan Bangsa-Bangsa kehilangan relevansinya dan dipertanyakan ulang nilai manfaatnya oleh banyak kalangan. Upaya menggantikannya adalah dengan konsep Dialog Antar Agama. ${ }^{39}$

Menurut penulis, seseorang akan berpikir dua kali untuk melakukan suatu kejahatan. Mengapa orang takut berbuat kejahatan? Salah satu jawabnya adalah karena adanya dan mengetahui adanya sanksi. Selama ini di Indonesia, tidak terdapat "sanksi ringan" bagi pemerintah yang tidak menunaikan amanat konstitusi dalam konteks kebebasan beragama dan belum terbentuk regulasi untuk mewujudkan apa yang diharuskan oleh pemerintah berdasarkan amanat konstitusi. Oleh karena itu, menurut penulis, harus ada sanksi yang tegas terhadap pelanggaran hak asasi manusia di bidang hak atas kebebasan beragama bagi pemerintah, baik yang bersifat ringan, atau bahkan yang bersifat berat sehingga pemahaman atas kejahatan tidak hanya berlaku bagi warga negara, akan tetapi juga berlaku kepada para elit negara.

\section{Pemenuhan terhadap Hak atas Pekerjaan}

Kajian mengenai pemenuhan terhadap hak atas pekerjaan memiliki aspek (ruang lingkup) yang luas. Oleh karena itu, dalam penelitian ini, kajian tersebut dibatasi terhadap pentingnya regulasi oleh pembentuk undang-undang dalam

38 Fawaizul Umam, "Kala Beragama Tak Lagi Merdeka: Majelis Ulama Indonesia dalam Praksis Kebebasan Beragama", Jakarta: Kencana, 2015, hlm. 271.

39 M. Amin Abdullah, "Kebebasan Beragama atau Dialog Antaragama: 50 Tahun Hak Asasi Manusia", Jurnal Orientasi Baru Volume 11, Tahun 1998, hlm. 59. 
mengatur peran dan pemberian sanksi bagi pemerintah dalam konteks (ruang lingkup) terpenuhinya hak atas pekerjaan bagi setiap manusia yang berada di Indonesia.

Secara teknis, jelas tidak mungkin pengusaha akan merekrut pekerja/buruh jika tidak tersedia pekerjaan sesuai dengan kapasitas kebutuhan perusahaannya. Secara yuridis unsur ini merupakan salah satu syarat sahnya perjanjian kerja. Di mana unsur adanya pekerjaan sebagai syarat objektif dari perjanjian kerja sehingga objek perjanjian kerja harus jelas. Jika syarat objektif tidak terpenuhi, perjanjian kerja batal demi hukum. ${ }^{40}$

Berdasarkan hal di atas, dapat dikatakan bahwa pemenuhan terhadap hak atas pekerjaan memiliki korelasi dengan jenis hak-hak lainnya yang sudah dijamin di dalam konstitusi (di antaranya adalah hak atas pendidikan, hak atas kesehatan, dan lain sebagainya) sehingga seorang pekerja dapat memiliki kompetensi sesuai dengan apa yang diharapkan oleh perusahaan.

Islam menempatkan setiap manusia apapun jenis profesinya dalam posisi yang mulia dan terhormat. Hal ini disebabkan Islam sangat mencintai umat Islam yang gigih bekerja untuk kehidupannya. Allah menegaskan dalam Q.S. Al-Jumu'ah ayat 10 yang artinya sebagai berikut: "Apabila telah ditunaikan shalat, maka bertebaranlah kamu di muka bumi; dan carilah karunia Allah dan ingatlah Allah banyak-banyak supaya kamu beruntung." Islam tidak hanya menempatkan bekerja sebagai hak tetapi juga kewajiban. Bekerja merupakan kehormatan yang perlu dijamin. Rasulullah bersabda, yang artinya: "Tidak ada makanan yang lebih baik yang dimakan seseorang daripada

\footnotetext{
40 Abdul Khakim, Dasar-dasar Hukum Ketenagakerjaan, (Bandung: Citra Aditya Bakti, 2009), hlm. 43.
}

makanan yang dihasilkan dari usaha tangannya sendiri". (HR Bukhary). ${ }^{41}$

Jaminan terhadap hak atas pekerjaan menandakan bahwa manusia dihormati sebagai makhluk yang mampu mengembangkan dan menentukan dirinya sendiri. Dengan kerja pula manusia membebaskan dirinya dari ketergantungan yang negatif pada orang lain. Bersamaan dengan itu, melalui kerja ia menegaskan dirinya, identitasnya, dan eksistensinya. Dengan kata lain, kerja berkaitan dengan harkat dan martabat manusia sebagai manusia. Karena itu, kerja harus dianggap sebagai salah satu hak asasi manusia. Ini berarti pengangguran merupakan negasi terhadap kemanusiaan manusia, terhadap harkat dan martabat manusia, dan karena itu harus diberantas. ${ }^{42}$

Fenomena banyaknya pengangguran tak henti menjadi pembahasan negara, karena menjadi tugas pemerintah untuk menyediakan lebih banyak lapangan pekerjaan, demi memenuhi hak konstitusional warga negara. ${ }^{43}$ Pengangguran merupakan suatu situasi yang pantas dibasmi karena bertentangan dengan hak atas pekerjaan dan bertentangan dengan harkat dan martabat manusia. Karena itu, persoalan pengangguran bukan sekadar persoalan ekonomi atau kehidupan ekonomi, melainkan berkaitan dengan persoalan eksistensial: keberadaan manusia sebagai manusia. Bisa dimengerti bahwa pengangguran lalu menjadi situasi yang menekan dan membelenggu bukan hanya karena soal ekonomi melainkan juga karena melahirkan situasi yang tidak manusiawi yang terungkap dalam

41 Muhammad Zaini, Op. Cit., hlm. 16-17.

42 A. Sonny Keraf, Etika Bisnis: Tuntunan dan Relevansinya, (Yogyakarta: Kanisius, 1998), hlm. 163.

43 Siti Nurhalimah, "Perlindungan Hukum terhadap Tenaga Kerja Indonesia”, 'Adalah: Buletin Hukum \& Keadilan, Volume 1 Nomor 1c (2017), hlm. 5. 
berbagai gejala psikologis yang memprihatinkan. ${ }^{44}$

Jumlah pengangguran yang mencapai angka jutaan, menyebabkan pemerintah Indonesia dituntut untuk secara bertahap mengurangi jumlah tersebut sesuai dengan kemampuan negara. Namun jika negara gagal melakukan kewajibannya tersebut, maka pemerintah dianggap telah melanggar hak asasi manusia. Model penyelesaian pelanggaran terhadap isi Kovenan ini di Indonesia belum tersedia, sehingga masyarakat yang ingin menuntut pemenuhan terhadap hak ini tidak dapat melakukannya secara serta merta kepada pengadilan. Hal yang dapat dilakukan oleh masyarakat adalah meminta organisasi non pemerintah untuk melakukan advokasi terhadap kepentingan-kepentingan masyarakat. ${ }^{45}$

Berdasarkan hal tersebut di atas, oleh karena tidak ada regulasi sebagai pedoman bagi pemerintah Indonesia dalam mengurangi jumlah pengangguran, maka suatu hal yang wajar sampai saat ini, tida ada sanksi bagi pemerintah apabila gagal melakukan kewajibannya tersebut.

Pemerintah (hanya, pen) memiliki peraturan-peraturan yang dimaksudkan untuk menjamin hak-hak anak dan telah memulai inisiatif-inisiatif untuk menyediakan perlindungan bagi mereka. Tetapi usaha-usaha ini masih mengandung banyak kontradiksi dan tidak tuntas. ${ }^{46}$ Persoalannya menurut penulis disebabkan oleh berbagai faktor yang terkait dengan persoalan hak asasi manusia lainnya, satu diantaranya adalah terkait dengan hak atas pendidikan.

44 A. Sonny Keraf, Op. Cit., hlm. 163-164.

45 Eko Riyadi dan Syarif Nurhidayat (Editor), Vulnerable Groups: Kajian dan Mekanisme Perlindungannya, (Yogyakarta: PUSHAM UII, 2012), hlm. 32.

46 Human Rights Watch, Pekerja di dalam BayangBayang Pelecehan dan Eksploitasi terhadap Pekerja Rumah Tangga Anak di Indonesia, 2009, hlm. 5.
Di antara tujuan yang diharapkan orang tua dari anak-anaknya dalam pendidikan, tidak lain adalah untuk memperbaiki akhlak anak-anak mereka, agar mereka bisa memperdalam ilmu, supaya anak-anak mereka lebih pintar dari pada orangtuanya, agar kehidupan anaknya kelak bisa lebih baik dari pada sekarang, serta ada yang bertujuan agar anaknya memiliki pekerjaan yang layak. Dan juga mengharapkan anaknya bekerja di pemerintahan. ${ }^{47}$

Orang yang berpendidikan tinggi tentu akan memiliki pekerjaan yang layak/baik, serta memiliki pendapatan yang tinggi pula, sehingga orang tua dengan kriteria seperti itu akan mengutamakan asupan gizi yang sesuai untuk anaknya serta memberikan yang terbaik demi menunjang tumbuh dan kembang anaknya. Lain halnya dengan orang tua yang memiliki pendidikan rendah, maka pengetahuan, keterampilan dan kemampuannya juga rendah. Dengan demikian otomatis peluang kerja akan lebih sedikit dan pendapatan juga rendah sehingga untuk memenuhi gizi anaknya akan susah terpenuhi. Sehingga daya tahan tubuh keluarga rendah dan menjadi rentan terhadap penyakit. Selain itu pendidikan juga berpengaruh terhadap pengetahuan tentang pentingnya kesehatan bagi dirinya dan keluarga. ${ }^{48}$

Secara ius constitutum, negara bertanggung jawab pada hak atas pekerjaan yang diakui dan dilindungi oleh Konstitusi Negara. Berdasarkan landasan konstitusional tersebut, negara

47 Mahfud dan Sofiyatun, "Makna Pendidikan bagi Kaum Marjinal (Studi terhadap Pandangan Tukang Becak di Pasar Sangkapura Bawean)", Cendekia: Jurnal Studi Keislaman, Volume 1, Nomor 1, Juni 2015, hlm. 31.

48 Anindita Hasniati Rahmah, Ruben Dharmawan, dan Setyo Sri Rahardjo, "Socioeconomic, Environmental, and Behavioral Determinants of Leprosy in Kediri, East Java", Journal of Epidemiology and Public Health (2018), 3(2): 253-262", hlm. 259. 
bertanggung jawab terhadap hak atas pekerjaan setiap warga negara dan setiap orang di negara ini, sehingga negara harus memenuhi, mengatur, dan melindungi hak konstitusional atas pekerjaan tersebut (baik terhadap pekerja outsourching, terhadap penyandang disabilitas, maupun terhadap perlindungan pekerja di luar negeri, pen). ${ }^{49}$ Dalam konteks outsourcing, diuraikan sebagai berikut.

Hak-hak tenaga kerja secara umum telah dirangkum dalam pelbagai aspek perlindungan, yaitu semasa, dalam tempo, maupun selepas tempo pekerjaan. ${ }^{50} \mathrm{UU} \quad$ Ketenagakerjaan memberi peluang terjadinya outsourcing yang memang dibutuhkan oleh pengusaha untuk efisiensi usaha demi kelangsungan hidup dari perusahaan tersebut. Kelangsungan hidup perusahaan juga sangat dibutuhkan untuk menciptakan lapangan keja yang pada akhirnya juga untuk kelangsungan hidup masyarakat Indonesia yang tidak semua mampu untuk berusaha sendiri. ${ }^{51}$ Oleh karena itu, pemerintah harus tegas dan harus mampu mengakomodir usulanusulan dari pihak organisasi-organisasi buruh yang sering menyuarakan tentang keadilan dan kesejahteraan buruh. Jangan hanya dijadikan corong dan melindungi pengusaha saja, tapi juga harus memperhatikan rasa keadilan dan kesejahteraan kaum buruh. ${ }^{52}$

49 Widodo Suryandono, Tenaga Kerja Asing: Analisis Politik Hukum, (Jakarta: Yayasan Pustaka Obor Indonesia, 2017), hlm. 13.

50 Taufiq A. Rashid, Fabli Yusof, Ahmad Irfan Jailani, dan Tuan Nurhafiza Raja Abdul Aziz, "Dasar-dasar Persefahaman Malaysia dan Indonesia dalam Melindungi Tenaga Kerja Asing", Journal of Law \& Governance, Volume 1 (No. 1) 2018: 91-100, hlm. 99.

51 Syarifa Mahila, "Perlindungan Hukum Hak Pekerja Outsourcing Pasca Putusan Mahkamah Konstitusi”, Jurnal Lex Specialis, No 16 (2012), Desember, hlm. 54.

52 Heru Suyanto, Andriyanto Adhi Nugroho, "Perlindungan Hukum terhadap Hak-hak Pekerja
Selanjutnya, dalam konteks disabilitas dikaitkan dengan hak atas pekerjaan, diuraikan sebagai berikut. Berbagai undang-undang dan peraturan pemerintah di beberapa negara termasuk Indonesia, telah ditetapkan guna melarang diskriminasi atas dasar disabilitas terhadap segala bentuk pekerjaan, mencakup kondisi perekrutan, keterampilan, pelayanan penempatan dan keahlian serta pelatihan keterampilan dan berkelanjutan. Namun tidak tersedianya layanan informasi yang lengkap mengenai potensi dan kemampuan tenaga kerja penyandang disabilitas yang dapat diakses oleh pelaku usaha masih menjadi hambatan. Disamping itu berdasarkan analisis undang-undang maka undang-undang tersebut sudah memberikan perlindungan terhadap kaum penyandang disabilitas dengan baik, sehingga dalam mewujudkan hak penyandang disabilitas untuk memperoleh pekerjaan sudah terjamin dan dilindungi namun tetap dalam aplikasinya masih belum terlihat. ${ }^{53}$

Pemerintah terkesan masih memberikan perlindungan hukum secara diskriminatif terhadap penyandang disabilitas untuk memperoleh pendidikan dan pekerjaan yang layak. Meskipun regulasi tentang ini sudah cukup lengkap pada level UUD NRI Tahun 1945 dan UU. $^{54}$

Saran berkenaan dengan tanggung jawab negara terhadap pemenuhan hak untuk mendapatkan pekerjaan bagi

Outsourcing Berdasarkan Asas Keadilan”, Jurnal Yuridis, Vol 3, No 2 (2016), hlm. 12.

53 Pramadita Hasbullah dan Rahayu, "Hak Asasi Manusia bagi Penyandang Disabilitas dalam Mendapat Pekerjaan yang Layak Tanpa Adanya Diskriminasi", Hukum dan Dinamika Masyarakat Vol. 15 No. 2 April 2018, hlm. 153.

54 Jazim Hamidi, "Perlindungan Hukum terhadap Disabilitas dalam Memenuhi Hak Mendapatkan Pendidikan dan Pekerjaan", Jurnal Hukum Ius Quia Iustum No. 4 Vol. 23 Oktober 2016: 652 - 671, hlm. 669. 
disabilitas, yaitu: a. Penyandang disabilitas harus optimis untuk mendapatkan kesempatan melanjutkan pendidikan setinggitingginya dengan harapan berkesempatan mendapatkan pekerjaan yang layak pada sektor negara maupun swasta. b. Pemerintah, Pengusaha, LSM, dan Kelompok Profesi, harus menempatkan kelompok penyandang disabilitas menjadi layaknya teman sendiri, penuh empati, dan memfasilitasi sesuai kapabilitas dan kompetensiya masing-masing. Masyarakat juga harus mendorong keluarga dan teman-temannya penyandang disabilitasnya untuk ikut berperan aktif dalam menciptakan pekerjaan bagi kehidupan mereka yang lebih layak. c. Para penyandang disailitas dalam memperjuangkan hak-haknya, perlu bantuan hukum dalam upayanya untuk memperoleh ha-haknya juga dalam menyelesaikan perkara yang mungkin dihadapinya baik melalui jalur litigasi dan litigasi. ${ }^{55}$

Selanjutnya, dalam konteks pekerja di luar negeri dikaitkan dengan hak atas pekerjaan, diuraikan sebagai berikut. Bagi banyak penduduk Indonesia, berbagai faktor internal dan eksternal telah mempersempit lapangan kesempatan kerja di dalam negeri sehingga mengadu keuntungan dengan bekerja di luar negeri tidaklah menjadi pilihan atau kesempatan kerja alternatif, melainkan cenderung karena keterpaksaan. Memperhatikan kondisi ekonomi, bekerja di luar negeri untuk memperoleh penghasilan yang cukup menjadi pilihan yang paling masuk akal, satu-satunya yang ada dan itupun melalui sektor informal. $^{56}$

\footnotetext{
55 Ibid., hlm. 669-670.

56 Bareta, Rizky Dian dan Ispriyarso, Budi, "Politik Hukum Perlindungan Tenaga Kerja Indonesia Fase Purna Bekerja", Kanun Jurnal Ilmu Hukum, Vol. 20, No. 1, (April, 2018), pp. 163-181, hlm. 165-166.
}

Sejumlah penelitian baru-baru ini mempertanyakan asumsi yang mengatakan bahwa kaum pendatang mengancam tarap hidup rakyat Amerika. Namun kalaupun ada "ancaman" atas lapangan kerja, ancaman itu jangan disingkirkan dengan mengorbankan kebebasan. Dalam masyarakat yang bebas dan kompetitif, setiap orang memiliki hak atas pekerjaan atau tingkat penghasilan tertentu sebagaimana atlet harus mempertahankan rekor dunianya. ${ }^{57}$

\section{PENUTUP}

\section{Simpulan}

Kesimpulan dari penelitian ini adalah:

1. Regulasi tentang peran dan pemberian sanksi bagi pemerintah dalam konteks terjaminnya kebebasan beragama, terlebih pada pemeluk agama Islam, adalah hal yang sangat penting. Salah satu bentuk kekosongan hukum dalam regulasi kebebasan beragama di Indonesia adalah dalam konteks keluarnya seseorang dari agama Islam yang bertujuan untuk menyelamatkan manusia (tentu juga bagi pemeluk agama lainnya di Indonesia) dan memeluk agama lain atas kehendaknya sendiri dan tanpa paksaan siapapun. Kebebasan untuk memeluk agama sudah dijamin di Indonesia. Di Indonesia seringkali lahir aliran keagamaan yang oleh para ulama dinilai dan dinyatakan sesat dan pada langkah selanjutnya oleh negara dibubarkan dan dinyatakan terlarang. Hal ini antara lain

\footnotetext{
57 Widodo Suryandono, Tenaga Kerja Asing: Analisis Politik Hukum, (Jakarta: Yayasan Pustaka Obor Indonesia, 2017), hlm. 13.
} 
dialami oleh aliran Islam Jamaah, Inkarussunnah ataupun aliran Lemkari (Lembaga Karyawan Dakwah Islam). Hasil survei LSI memperlihatkan makin tingginya tingkat intoleransi beragama di kalangan masyarakat. Dalam survei ini, LSI mengambil dua isu mutakhir: kekerasan terhadap penganut Ahmadiyah dan pendirian rumah ibadah. Berkaitan dengan Ahmadiyah, hasil survei memperlihatkan pembenaran terhadap kekerasan pada warga Ahmadiyah makin tinggi.

2. Regulasi tentang peran dan pemberian sanksi bagi pemerintah dalam konteks terjaminnya hak untuk memperoleh pekerjaan yang layak, terlebih pada usia produktif, adalah hal yang sangat penting. Secara teknis, jelas tidak mungkin pengusaha akan merekrut pekerja/buruh jika tidak tersedia pekerjaan sesuai dengan kapasitas kebutuhan perusahaannya. Dari hal ini maka dapat dikatakan bahwa pemenuhan terhadap hak atas pekerjaan memiliki korelasi dengan jenis hak-hak lainnya sehingga seorang pekerja dapat memiliki kompetensi. Jumlah pengangguran yang tidak bisa dikurangi oleh pemerintah Indonesia dan perlakuan yang diskriminatif adalah bentuk

\section{Saran} pelanggaran hak atas pekerjaan.

Rekomendasi yang diberikan berdasarkan hasil penelitian ini adalah:

1. Pemerintah harus tegas mengkritik aksi kekerasan pada warga yang berbeda keyakinan. Dengan sikap tegas pemerintah, kebebasan warga dalam beribadah dapat terus dijamin. Dan keyakinan warga untuk beribadah dan menjalankan keyakinannya bisa terus dipupuk.

2. Hendaknya pemerintah secara bertahap mengurangi jumlah pengangguran sesuai dengan kemampuan negara. Selain itu, perlu kiranya dibentuk peraturan perundang-undangan mengenai model penyelesaian terhadap pelanggaran hak atas pekerjaan sehingga masyarakat dapat menuntut pemenuhan terhadap hak ini kepada pengadilan atau lembaga yang secara khusus dibentuk oleh pemerintah, meskipun pemerintah turut menjadi bagian dari pihak yang dapat dipermasalahakan secara hukum.

\section{DAFTAR PUSTAKA}

\section{Buku}

Asplund, Knut D., Marzuki, Suparman., dan Riyadi, Eko (Penyunting/Editor). Hukum Hak Asasi Manusia, Yogyakarta: PUSHAM UII, 2008.

Asshiddiqie, Jimly dan Safa'at, M. Ali. Teori Hans Kelsen tentang Hukum, Jakarta: Sekretariat Jenderal dan Kepaniteraan Mahkamah Konstitusi RI, 2006.

Asshiddiqie, Jimly. Konstitusi dan Konstitusionalisme Indonesia, Jakarta: Konstitusi Press, 2005.

Hamidi, Jazim dan Abadi, M. Husnu. Intervensi Negara Terhadap Agama: Studi Konvergensi atas Politik Aliran Keagamaan dan Reposisi Peradilan Agama di Indonesia, Yogyakarta: UII Press, 2001.

Harahap, A. Bazar dan Sutardi, Nawangsih. Hak Asasi Manusia dan Hukumnya, Jakarta: Pecirindo, 2006.

Human Rights Watch, Pekerja di dalam BayangBayang Pelecehan dan Eksploitasi terhadap Pekerja Rumah Tangga Anak di Indonesia, 2009. 
Keraf, A. Sonny. Etika Bisnis: Tuntunan dan Relevansinya, Yogyakarta: Kanisius, 1998.

Khakim, Abdul. Dasar-dasar Hukum Ketenagakerjaan, Bandung: Citra Aditya Bakti, 2009.

Laporan The Wahid Institute: Ringkasan Eksekutif Laporan Akhir Tahun Kebebasan Beragama dan Intoleransi 2012, Kerjasama The Wahid Institute dan Yayasan Tifa.

Manan, Bagir. Perkembangan Pemikiran dan Pengaturan Hak Asasi Manusia di Indonesia, Jakarta: Yayasan Hak Asasi Manusia, Demokrasi dan Supremasi Hukum, Alumni, 2006.

Maris, Masri (Penerjemah), Kebebasan dan Kebudayaan: Gagasan tentang Masyarakat Bebas, Jakarta: Yayasan Obor Indonesia, 2006.

Muhshi, Adam. "Teologi Konstitusi: Hukum Hak Asasi Manusia atas Kebebasan Beragama di Indonesia", Yogyakarta: Lkis Pelangi Aksara, 2015.

Muhtaj, Majda El. Dimensi-dimensi HAM: Mengurai Hak Ekonomi, Sosial, dan Budaya, Jakarta: RajaGrafindo Persada, 2008.

Riyadi, Eko dan Abdi, Supriyanto (Editor). Mengurai Kompleksitas Hak Asasi Manusia (Kajian Multi Perspektif), Yogyakarta: Pusat Studi Hak Asasi Manusia Universitas Islam Indonesia (PUSHAM UII), 2007.

Riyadi, Eko dan Nurhidayat, Syarif (Editor). Vulnerable Groups: Kajian dan Mekanisme Perlindungannya, Yogyakarta: PUSHAM UII, 2012.

Suryandono, Widodo. Tenaga Kerja Asing: Analisis Politik Hukum, Jakarta: Yayasan Pustaka Obor Indonesia, 2017.

Syahrizal, Ahmad. Peradilan Konsitusi, Jakarta: Pradnya Paramita, 2006.

Tim Penyusun Revisi Naskah Komprehensif, Perubahan Undang-Undang Dasar Negara Republik Indonesia Tahun 1945, Latar Belakang, Proses, dan Hasil Pembahasan 1999-2002, Buku VIII Warga Negara dan Penduduk, Hak Asasi Manusia, dan Agama, Jakarta: Sekretariat Jenderal dan Kepaniteraan Mahkamah Konstitusi, 2010.
Umam, Fawaizul. "Kala Beragama Tak Lagi Merdeka: Majelis Ulama Indonesia dalam Praksis Kebebasan Beragama", Jakarta: Kencana, 2015.

Yusran, Andi. Dinamika Politik Indonesia: Dari Transisi ke Transisi, Pekanbaru: The Institute for Regional Development and Policy Studies (ReD PoSt Institute), 2006.

Zen, A. Patra M., dan Hutagalung, Daniel (Editor). Panduan Bantuan Hukum di Indonesia: Pedoman Anda Memahami dan Menyelesaikan Masalah Hukum, Jakarta: YLBHI, 2006.

\section{Artikel}

\section{Artikel Jurnal yang Dicetak}

Abdullah, M. Amin. "Kebebasan Beragama atau Dialog Antaragama: 50 Tahun Hak Asasi Manusia”, Jurnal Orientasi Baru Volume 11, Tahun 1998.

Arif, Mahmud. "Islam Humanis, HAM, dan Humanisasi Pendidikan: Eksposisi Integratif Prinsip Dasar Islam, Kebebasan Beragama, Kesetaraan Gender, dan Pendidikan Humanis", Musâwa, Vol. 15 No. 2 Juli 2016.

Arifin, Stephanus Tilung. "Proses Hukum bagi Pelaku Kejahatan Penodaan Agama dalam Hubungannya dengan Kebebasan Beragama menurut Hak Asasi Manusia di Indonesia", Lex et Societatis, Vol. IV/No. 4/Apr/2016.

Bareta, Dian, Rizky., dan Ispriyarso. Budi, "Politik Hukum Perlindungan Tenaga Kerja Indonesia Fase Purna Bekerja", Kanun Jurnal Ilmu Hukum, Vol. 20, No. 1, (April, 2018), pp. 163-181.

Hamidi, Jazim. "Perlindungan Hukum terhadap Disabilitas dalam Memenuhi Hak Mendapatkan Pendidikan dan Pekerjaan", Jurnal Hukum Ius Quia Iustum No. 4 Vol. 23 Oktober 2016: 652 $-671$.

Hasan, Moh Abdul Kholiq. "Ayat-ayat Kebebasan Beragama dalam Perspektif Nasakh: Kajian terhadap Penafsiran Ibn Kathîr dan Rashîd Ridâ", Mutawâtir: Jurnal Keilmuan Tafsir Hadis Volume 6, Nomor 2, Desember 2016.

Hasbullah, Pramadita dan Rahayu. "Hak Asasi Manusia bagi Penyandang Disabilitas 
dalam Mendapat Pekerjaan yang Layak Tanpa Adanya Diskriminasi”, Hukum dan Dinamika Masyarakat Vol. 15 No. 2 April 2018.

Lingkaran Survei Indonesia, Meningkatkan Intoleransi Beragama Masyarakat Indonesia, Kajian Bulanan Edisi No. 23, Oktober 2010.

Mahfud dan Sofiyatun. "Makna Pendidikan bagi Kaum Marjinal (Studi terhadap Pandangan Tukang Becak di Pasar Sangkapura Bawean)", Cendekia: Jurnal Studi Keislaman, Volume 1, Nomor 1, Juni 2015.

Mahila, Syarifa. "Perlindungan Hukum Hak Pekerja Outsourcing Pasca Putusan Mahkamah Konstitusi", Jurnal Lex Specialis, No 16 (2012), Desember.

Nawawi, M. Anwar. "Kebebasan Beragama di Indonesia (Studi Jemaat Ahmadiyah dalam Perspektif Majelis Ulama Indonesia dan Komisi Nasional Hak Asasi Manusia)", Fikri, Vol. 3, No. 1, Juni 2018.

Nurhalimah, Siti. "Perlindungan Hukum terhadap Tenaga Kerja Indonesia", 'Adalah: Buletin Hukum \& Keadilan, Volume 1 Nomor 1c (2017).

Permana, Irfan Setia. "Pemerintah dan Hak Beragama di Indonesia (Peran Pemerintah dalam Memelihara Hak Beragama di Indonesia)", TEDC Vol. 12 No. 2, Mei 2018.

Putra, Dedi. "Membangun Kembali Nilai-nilai Dasar Keislaman sebagai Resolusi Konflik Ahmadiyah: Diskursus Hak Kebebasan Beragama dan Berkeyakinan", Ri'ayah, Vol. 02, No. 01 Januari-Juni 2017.

Rahmah, Anindita Hasniati., Dharmawan, Ruben., dan Rahardjo, Setyo Sri., "Socioeconomic, Environmental, and Behavioral Determinants of Leprosy in Kediri, East Java", Journal of Epidemiology and Public Health (2018), 3(2): 253-262".

Rashid, Taufiq A., Yusof, Fabli., Jailani, Ahmad Irfan., dan Aziz, Tuan Nurhafiza Raja Abdul. "Dasar-dasar Persefahaman Malaysia dan Indonesia dalam Melindungi Tenaga Kerja Asing”, Journal of Law \& Governance, Volume 1 (No. 1) 2018: 91-100.
Suyanto, Heru dan Nugroho, Andriyanto Adhi. "Perlindungan Hukum terhadap Hak-hak Pekerja Outsourcing Berdasarkan Asas Keadilan”, Jurnal Yuridis, Vol 3, No 2 (2016).

Zaini, Muhammad. "Hak Asasi Manusia menurut Al-Qur'an dan Hadis Nabi Saw", AlMu'ashirah Vol. 13, No. 1, Januari 2016.

\section{Artikel Jurnal Online}

Mutawali, Muhammad. "Murtad: Antara Hukuman Mati dan Kebebasan Beragama", (2017, October 28), diakses tanggal 17 Desember 2018, doi: https://doi.org/10.31219/osf.io/dgaxk.

\section{Peraturan Perundang-undangan}

Undang-Undang Dasar Negara Republik Indonesia Tahun 1945. 
AJUDIKASI : Jurnal Ilmu Hukum, Volume 3 Nomor 1, Juni 2019. Hlm 53-74 